\title{
Implementasi dan Analisis Teknik Reduksi PAPR OFDM Menggunakan Metode PTS pada WARP
}

\author{
Rizkha Ajeng Rochmatika, Titiek Suryani, Suwadi \\ Jurusan Teknik Elektro, Fakultas Teknologi Industri, Institut Teknologi Sepuluh Nopember (ITS) \\ Jl. Arief Rahman Hakim, Surabaya 60111 \\ e-mail: titiks@ee.its.ac.id, suwadi@ee.its.ac.id, rizkha12@mhs.ee.its.ac.id
}

\begin{abstract}
Abstrak - Sistem OFDM cocok digunakan sebagai solusi yang dapat memenuhi layanan komunikasi data kecepatan tinggi karena memiliki efisiensi bandwidth dengan performansi terbaik. Namun dalam implementasinya, sistem OFDM memiliki kelemahan yang disebabkan oleh tingginya nilai Peak to Average Power Ratio (PAPR) sehingga sinyal OFDM rentan terkena distorsi nonlinear yang disebabkan oleh adanya komponen $R F$ power amplifier yang menyebabkan kompleksitas komponen Analog to Digital Converter (ADC) yang terdapat pada Wireless Open Access Research Platform (WARP). Nilai PAPR yang besar pada OFDM membutuhkan power amplifier dengan dynamic range yang lebar untuk mengakomodasi sinyal, apabila hal tersebut tidak terpenuhi maka menyebabkan distorsi nonlinear dan pada akhirnya menurunkan performansi OFDM. Oleh karena itu, untuk mengatasinya dibutuhkan suatu metode yang dapat mereduksi nilai PAPR salah satunya menggunakan metode PTS. Guna melihat unjuk kerja teknik PTS, maka pada penelitian ini dibandingkan dua skema antara sistem OFDM tanpa dan dengan teknik PTS menggunakan analisa pada bit error rate dan nilai CCDF.

Dari hasil pengukuran menunjukkan bahwa implementasi kinerja teknik PTS mampu meningkatkan kinerja sistem OFDM saat terkena distorsi nonlinear, terlihat pada pengukuran dengan modulasi 16-QAM untuk gain 56 didapatkan peningkatan BER sebesar $95.98 \%$. Sedangkan pada grafik CCDF terjadi penurunan nilai PAPR sebesar $34.17 \%$ untuk $M=4$.
\end{abstract}

Kata Kunci-OFDM, PTS, Distorsi Nonlinear, RF power amplifier, WARP

\section{PENDAHULUAN}

$\mathrm{T}$ UNTUTAN masyarakat terkait dengan komunikasi data yang cepat menyebabkan permintaan layanan komunikasi pita lebar semakin meningkat. Maka untuk memenuhi kebutuhan masyarakat tersebut dibutuhkan suatu sistem komunikasi yang memiliki efisiensi bandwidth dan layanan kecepatan akses tinggi secara realtime dengan performansi terbaik. Sistem OFDM (Orthogonal Frequency Division Multiplexing) adalah solusinya. OFDM merupakan suatu teknik modulasi multicarrier yang memiliki efisiensi tinggi dalam pemakaian frekuensi, kuat dalam menghadapi frequency selective fading, dan tidak sensitif terhadap sinyal delay. Sistem OFDM ini sudah digunakan sebagai standar komunikasi wireless yang berbeda-beda seperti standar IEEE 802.11a yang digunakan untuk Wireless Local Area Network (WLAN) dan standart IEEE 802.16a untuk Wireless Metropolitan Area Network (WMAN) [1].
Namun dalam implementasinya terdapat kerugian yang dapat disebabkan oleh sistem OFDM yaitu tingginya nilai PAPR (Peak Average Power Ratio) pada sinyal transmit. PAPR adalah perbandingan dari daya puncak dengan daya rata-rata sinyal. PAPR dapat terjadi akibat modulasi dari masing-masing subcarrier yang dilakukan dengan frekuensi yang berbedabeda, sehingga menyebabkan beberapa subcarrier mempunyai fasa koheren yang pada akhirnya akan muncul amplitudo dengan level jauh lebih besar dari daya sinyalnya [2].

Nilai PAPR yang besar mangakibatkan beberapa kerugian seperti meningkatnya kompleksitas ADC dan DAC serta mengurangi efisiensi dari RF power amplifier. Selain itu dapat menyebabkan rentan terhadap distorsi nonlinear karena sistem OFDM membutuhkan amplifier dengan dynamic range yang lebar untuk mengakomodasi amplitudo sinyal [3].

Oleh karena itu, untuk mengatasi hal tersebut ada beberapa teknik yang dapat digunakan untuk mereduksi nilai PAPR yaitu clipping, tone reservation, tone injection, coding, companding transforms, selected mapping (SLM), dan partial transmit sequence (PTS). Dalam penelitian tugas akhir ini, digunakan salah satu metode untuk mereduksi nilai PAPR yaitu menggunakan teknik PTS karena kinerjanya dinilai lebih efektif untuk mereduksi PAPR tanpa menimbulkan sinyal distorsi [4]. Teknik PTS ini merupakan bagian dari metode probabilistic atau pengacakan sinyal di mana bertujuan untuk mengacak input blok data simbol OFDM dan kemudian memilih nilai PAPR yang rendah untuk ditransmisikan.

Sehingga pada tugas akhir ini dilakukan perancangan sistem pereduksi PAPR pada OFDM dengan teknik PTS yang akan disimulasikan menggunakan software MATLAB dan diimplementasikan pada Wireless Open-Access Research Platform (WARP). Platform WARP merupakan salah satu jenis dari teknologi Software Define Radio (SDR) yang dapat mengimplementasikan algoritma wireless yang sangat kompleks. Namun dalam implementasi sistem komunikaasi wireless tersebut, pengaruh nonlinear dari RF Power Amplifier dapat menyebabkan terjadinya interferensi pada adjacent channel dan menurunkan performansi dari OFDM. Oleh karena itu, teknik reduksi PAPR diharapkan mampu untuk mengurangi pengaruh dari distorsi nonlinear yang timbul dari power amplifier tersebut. 


\section{TINJAUAN PUSTAKA}

\section{A. OFDM}

Teknik OFDM pada prinsipnya membagi laju transmisi berkecepatan tinggi menjadi beberapa laju berkecepatan rendah yang ditransmisikan secara simultan dengan menggunakan subchannel atau subcarrier yang saling orthogonal [5]. Jadi untuk setiap subcarrier memiliki frekuensi yang saling orthogonal sehingga membuat setiap subcarrier overlap namun tidak saling menimbulkan interferensi. Untuk jarak setiap frekuensi subcarrier agar orthogonal minimal harus dipisahkan sejauh 1/Ts dan dapat dinyatakan pada persamaan 1 [6].

$$
\Delta f=\frac{1}{T s}
$$

Di mana $\Delta f$ menunjukkan frequency carrier spacing dan Ts menunjukkan interval simbol OFDM. Keunggulan teknik OFDM adalah efisiensi bandwidth, tahan terhadap frequency selective fading dan mengatasi masalah inter-symbol interference (ISI).

\section{B. Peak Average Power Ratio (PAPR)}

PAPR adalah perbandingan antara daya sinyal puncak dengan daya rata-ratanya. PAPR terjadi karena dalam sistem OFDM terdiri atas penjumlahan sejumlah subcarrier yang dimodulasi secara independen. Apabila fase setiap subcarrier sama maka akan menghasilkan daya sinyal puncak sebesar $\mathrm{N}$ kali daya rata-ratanya. Oleh karena itu, dalam implementasinya nilai PAPR yang tinggi dapat menurunkan SQNR (Signal to Quantization Noise Ratio), mengurangi efisiensi daya amplifier dan meningkatkan cost dari RF power amplifier. Sehingga sistem OFDM membutuhkan dynamic range yang lebar untuk mengakomodasi amplitude sinyal pada power amplifier. Jika hal tersebut tidak terpenuhi maka akan terjadi distorsi nonlinear yang menyebabkan subcarrier menjadi tidak lagi orthogonal dan dapat menurunkan kinerja dari sistem OFDM. Power amplifier merupakan salah satu komponen sistem yang tidak linier. Idealnya, output dari PA setara dengan input yang diberikan dikalikan dengan gain factor. Namun pada kenyataannya, power amplifier mepunyai daerah linear yang terbatas diluar daerah saturasi. Secara matematis PAPR suatu sinyal $s(t)$ dirumuskan pada persamaan 2 sebagai berikut:

$$
P A P R=\frac{\max |s(t)|^{2}}{E\left\{|s(t)|^{2}\right\}}
$$

Untuk nilai PAPR dideskripsikan secara statistic dengan menggunakan Complementary Cumulative Distribution Function (CCDF). CCDF merupakan parameter untuk mengukur daya puncak dari sinyal OFDM yang berisi informasi mengenai sinyal OFDM yang memiliki PAPR di atas level tertentu dinyatakan sebagai berikut:

$$
C C D F=1-C D F
$$

$$
C C D F=1-\left(1-e^{-P A P R}\right)^{N}
$$

\section{Partial Transmit Sequence (PTS)}

PTS (Partial Transmit Sequence) adalah salah satu metode untuk mereduksi nilai PAPR pada sinyal OFDM. Ada tiga teknik yang digunakan untuk mempartisi data sequence menjadi beberapa sub-block yaitu adjacent partition, interleaved partition, dan pseudorandom partition. Pada penelitian ini menggunakan skema adjacent partition [7]. Pada gambar 1 dapat dilihat bahwa data informasi dalam domain frekuensi $X$ dipartisi menjadi $M$ sub-block. Tiap sub-block memiliki panjang sama sebesar $N$ subcarrier, terdiri dari $N / M$ elemen nonzero dan zero pada bagian akhir sub-block. Sebelum dikalikan dengan faktor pembobot, setiap sub-block melalui IFFT untuk proses perubahan domain kompleks menjadi domain waktu.

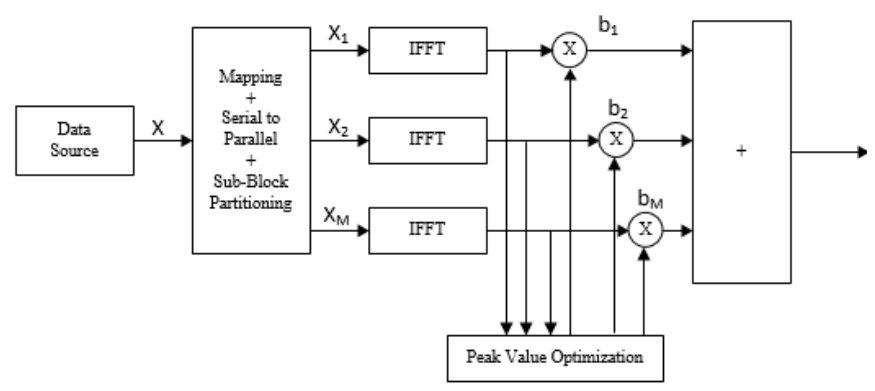

Gambar 1. Blok Diagram Partial Transmit Sequence

Untuk keluaran sinyal OFDM dengan faktor pembobot dapat dirumuskan seperti pada persamaan berikut.

$$
\begin{aligned}
x & =\sum_{m=1}^{m} b_{m} x_{m} \\
\text { untuk } \quad b_{m} & =e^{j \varphi m}, \varphi_{m}=[0,2 \pi]
\end{aligned}
$$

Di mana $b_{m}$ adalah faktor fasa yang diacak dari tiap sub-block kemudian dijumlahkan dan didapatkan factor fasa dengan nilai PAPR terendah sebelum sinyal OFDM ditransmisikan.

\section{Amplifier Distortion}

Nonlinearity yang ada pada daerah saturasi menunjukkan pengurangan nilai amplitude hampir lebih dari setengah sinyal aslinya [8]. Hal ini bisa disebabkan oleh karakteristik konversi AM/AM dan AM/PM berdasarkan frekuensi sinyal input.

Distorsi nonlinear pada amplifier menyebabkan pelemahan sinyal transmisi dengan berbagai macam cara. Efek yang ditimbulkan dari distorsi nonlinear sebagai berikut:

1. Menimbulkan interferensi nonlinear pada penerima

2. Konstelasi sinyal menjadi rusak dan menyebar

3. Terjadi penyebaran spektrum pada sinyal transmit yang dapat menyebabkan interferensi adjacent channel

4. Menyebabkan efek intermodulasi yang terjadi ketika beberapa kanal dikuatkan 

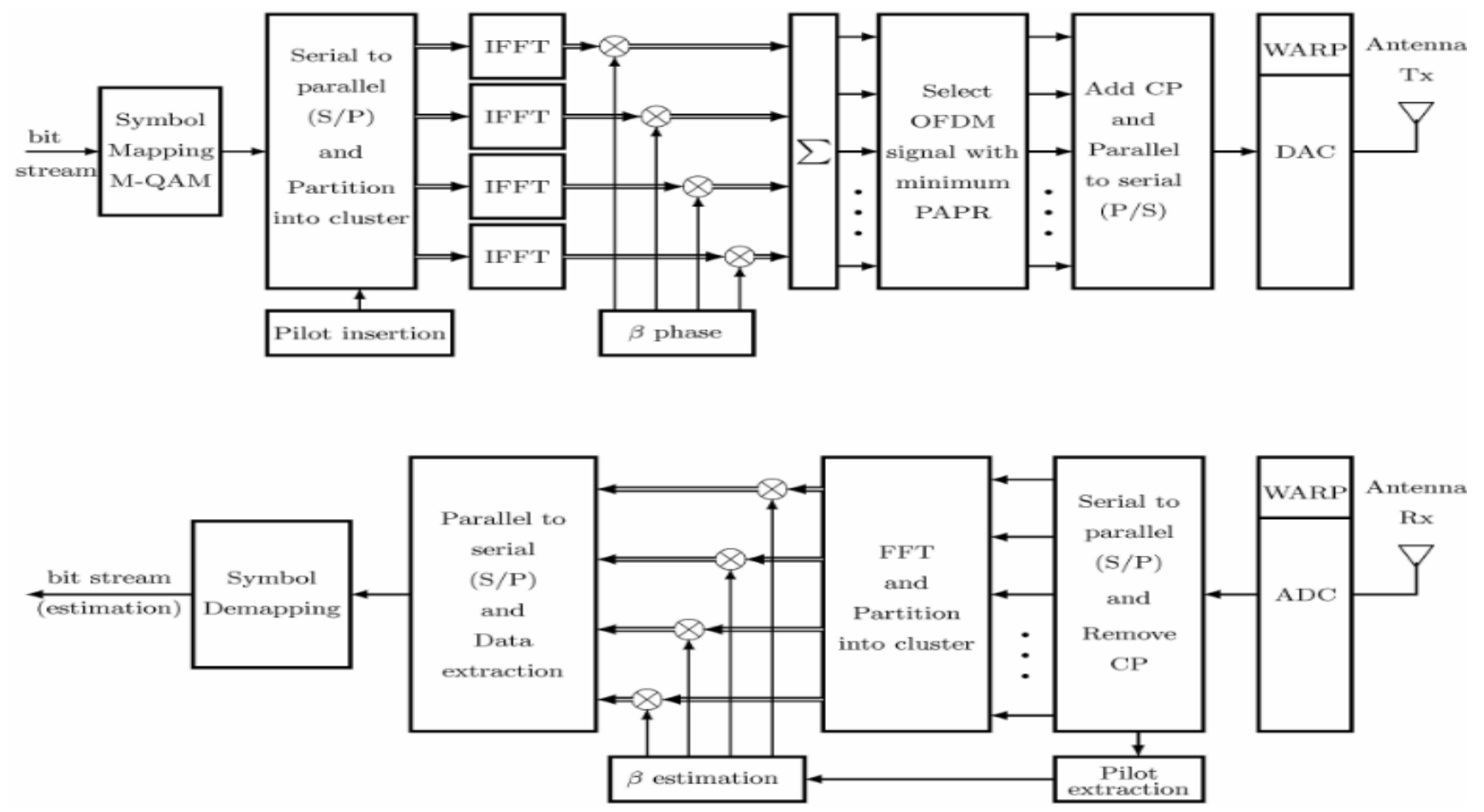

Gambar 2. Diagram blok sistem OFDM implementasi teknik PTS

\section{E. Kompleksitas ADC pada WARP}

Penyebab rentannya terjadi distorsi nonlinear pada implementasi OFDM di WARP adalah ketidaklinearan dari komponen Analog to Digital Converter pada receiver OFDM. Ada 2 macam eror yang disebabkan oleh kompleksitas ADC tersebut meningkat, yaitu [9]:

1. Quantization Error: Eror ini terjadi ketika gain $\alpha$ lebih kecil dari nilai optimum level power amplifier. Bisa dituliskan dalam persamaan 6 berikut [8]:

$$
\left|r_{a}\left(k T_{s}\right)\right|<M+\frac{\Delta_{q}}{2}
$$

Di mana $r_{a}$ adalah sinyal keluaran dari demodulator, $k$ adalah waktu diskirt, $T_{s}$ sebagai sinyal masukan yang disampling, $M$ adalah nilai maksimum dari range ADC dan $\Delta_{q}$ adalah ukuran quantizer.

2. Clipping Error: Eror ini terjadi ketika gain $\alpha$ lebih besar dari nilai optimum level power amplifier. Bisa dituliskan dalam persamaan 7 berikut [8]:

$$
\left|r_{a}\left(k T_{s}\right)\right|>M+\frac{\Delta_{q}}{2}
$$

\section{PERANCANGAN DAN IMPLEMENTASI}

\section{A. Model Saleh}

Sebelum diimplementasikan ke modul WARP, sistem OFDM implementasi teknik PTS perlu disimulasikan dulu menggunakan MATLAB untuk mengetahui efek dari distorsi nonlinear. Dalam simulasi MATLAB tersebut untuk memodelkan gangguan nonlinear dapat menggunkan model saleh yang bisa dilihat dengan script seperti pada gambar 3 dengan menggunakan kanal Additive White Gaussian Noise $(A W G N)$.

s.model Gangguan Nonlinier

hNonlin = comm.MemorylessNonlinearity ('Method', 'Saleh model'); tx_vec_air = step (hNonlin, Pa*tx_vec_air.');

tx_vec_air=tx_vec_air.' ;

Gambar 3. Pemodelan gangguan nonlinear

\section{B. Parameter Sistem OFDM Implementasi WARP}

Penentuan parameter sistem OFDM implementasi PTS pada modul WARP dapat dilihat pada tabel 1. Ada dua skema yang dianalisis dalam penelitian ini yaitu skema OFDM tanpa metode PTS dan OFDM dengan teknik PTS. Sedangkan parameter untuk pengukuran pada modul WARP dapat dilihat pada tabel 2 .

Tabel 1.

Parameter Implementasi Sistem OFDM

\begin{tabular}{ll}
\hline \hline Parameter & Besaran \\
\hline Jumlah Simbol OFDM & 90 \\
Panjang Cyclic Prefix & 16 \\
Jumlah subcarrier & 64 \\
Payload & 48 \\
Pilot & 4 \\
Null & 12 \\
Interpolasi & 2 kali \\
Modulasi & M-QAM \\
LTS & 0.6 \\
\hline \hline
\end{tabular}

Tabel 2.

Parameter Pengukuran Implementasi PTS pada WARP

\begin{tabular}{ll}
\hline \hline Parameter & Besaran \\
\hline Gain RF Tx & $50-60 \mathrm{~dB}$ \\
Gain Baseband $\mathrm{Tx}$ & $2 \mathrm{~dB}$ \\
Gain RF Rx & $2 \mathrm{~dB}$ \\
Gain Baseband $\mathrm{Rx}$ & $2 \mathrm{~dB}$ \\
Jarak Tx-Rx & 3 meter \\
Faktor Fasa PTS & {$[1-1 \mathrm{j}-\mathrm{j}]$} \\
Variasi sub-block & $2 \mathrm{dan} 4$ \\
Jumlah bit terkirim & 17280 bit dan \\
& 25920 bit \\
Correction (CFO, Phase, SFO) & Active \\
\hline \hline
\end{tabular}




\section{Sistem OFDM Implementasi PTS pada WARP}

Pada gambar 2 dijelaskan mengenai diagram blok dari sistem PTS yang diimplementasikan pada WARP dengan jumlah partisi sub-block 4. Awalnya sinyal dibangkitkan secara acak dan dimodulasi menggunakan modulasi M-QAM untuk mengubah bit informasi menjadi bilangan kompleks kemudian diubah ke bentuk parallel. Implementasi teknik PTS diberikan dengan cara membagi blok IFFT (Inverse Fast Fourier Transform) menjadi 4 sub-block. Di mana pada tiap sub-block berisi subcarrier. Dengan panjang subcarrier 64 dibagi ke dalam 4 sub-block menjadi 16 subcarrier tiap sub-block. Untuk sub-block pertama nilai subcarrier terletak pada urutan 1-16 dan urutan 17-64 bernilai 0. Untuk sub-block kedua nilai subcarrier terletak pada urutan 17-32 sedangkan urutan 1-16 dan 33-64 bernilai 0. Untuk sub-block ketiga nilai subcarrier terletak pada urutan 33-48 sedangkan urutan 1-32 dan 49-64 bernilai 0. Sub-block terkahir nilai subcarrier terletak pada urutan 49-64 dan urutan 1-48 bernilai 0. Pada tiap sub-block tersebut dikalikan dengan 4 faktor fasa yang sudah ditentukan, $b=\left[\begin{array}{ll}1 & -1 \mathrm{j}-\mathrm{j}\end{array}\right]$, menggunakan persamaan rumus 4 yang sudah dijelaskan sebelumnya. Sehingga untuk setiap faktor fasa terdapat 64 probabilitas. Jika terdapat 4 faktor fasa jadi terdapat 256 probabilitas. Sehingga dari keempat factor fasa tersebut dicari yang memiliki nilai PAPR terendah untuk kemudian sinyal bisa ditransmisikan. Optimasi pemilihan factor fasa tersebut dilakukan untuk mengurangi terjadinya efek distorsi nonlinear pada kanal WARP. Sebelum ditransmisikan, sinyal diubah dulu ke bentuk serial dan ditambah dengan cyclic prefix yang berguna untuk menentukan simbol pertama OFDM ketika sampai di receiver.

Selanjutnya sinyal diterima di receiver dan mengalami proses yang berkebalikan dengan di transmitter. Untuk implementasi teknik PTS pada receiver terjadi pada proses FFT (Fast Fourier Transform) yang merupakan kebalikan dari proses IFFT. Di dalam proses FFT domain waktu diubah kembali ke domain frekuensi dan terjadi partisi block karena adanya implementasi teknik reduksi PAPR. Partisi block dibagi menjadi empat sub-block sesuai dengan partisi block pada saat terjadi proses IFFT. Jika di awal sub-block dikalikan dengan faktor fasa maka dalam proses FFT ini sub-block kembali dikalikan dengan conjugate faktor fasa. Hal itu dilakukan untuk mengestimasi kanal yang didapatkan dari proses korelasi Long Training Symbol (LTS) dan error phase dengan menggunakan pilot. Proses ini biasa disebut dengan proses equalizer.

Proses terakhir yaitu demapping bertujuan untuk mengubah deretan simbol OFDM menjadi bit-bit informasi kembali. Keluaran dari bit informasi tersebut dapat digunakan untuk mengetahui nilai BER (bit error rate) atau kesalahan bit yang diterima pada receiver dibandingkan dengan bit informasi yang dibangkitkan pada transmitter. Hasil BER yang didapatkan dapat digunakan sebagai perbandingan nilai ketika sistem OFDM diimplementasikan pada WARP menggunakan teknik PTS dan tanpa teknik PTS dengan adanya pengaruh distorsi nonlinear pada gain tinggi modul WARP.

\section{ANALISIS HASIL IMPLEMENTASI PTS}

\section{A. Analisis Grafik CCDF}

Hasil perbandingan analisis penurunan grafik CCDF untuk kedua skema pada modulasi M-QAM ditunjukkan pada tabel 3. Berdasarkan grafik CCDF pada gambar 4 dan 5, didapatkan penurunan PAPR implementasi teknik PTS untuk sub-block 4 pada modulasi 16-QAM lebih besar yaitu 34.17\% sedangkan pada modulasi 64-QAM untuk gambar 6 dan 7 penurunan PAPR sebesar $40.94 \%$. Hal itu menunjukkan semakin besar jumlah sub-block penurunan PAPR semakin besar.

Tabel 3 .

Hasil Penurunan Grafik CCDF Modulasi M-QAM

\begin{tabular}{clccc}
\hline \hline \multirow{2}{*}{ Modulasi } & $\begin{array}{c}\text { Jumlah } \\
\text { Sub-block }\end{array}$ & $\begin{array}{c}\text { PAPR } \\
\text { OFDM }\end{array}$ & $\begin{array}{c}\text { PAPR } \\
\text { PTS }\end{array}$ & $\begin{array}{c}\text { Prosentase Penurunan } \\
\text { PAPR (\%) }\end{array}$ \\
\hline 16-QAM & $\mathrm{M}=2$ & 8.993 & 8.805 & $2.09 \%$ \\
16-QAM & $\mathrm{M}=4$ & 8.993 & 5.92 & $34.17 \%$ \\
64-QAM & $\mathrm{M}=2$ & 9.767 & 8.53 & $12.66 \%$ \\
64-QAM & $\mathrm{M}=4$ & 9.767 & 5.768 & $40.94 \%$ \\
\hline \hline
\end{tabular}

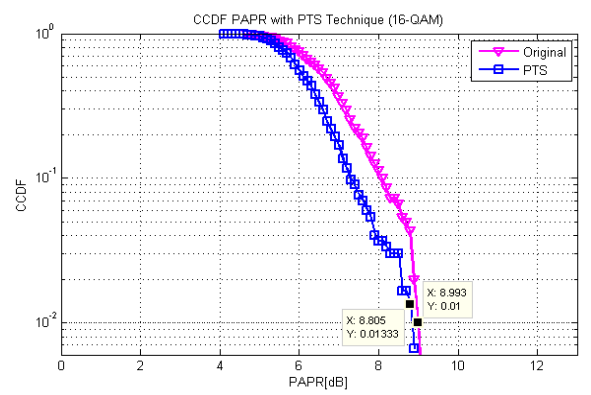

Gambar 4. Grafik CCDF untuk 16-QAM Sub-block 2

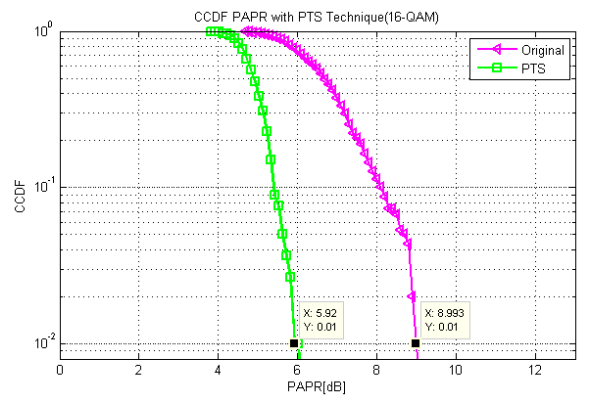

Gambar 5. Grafik CCDF untuk 16-QAM Sub-block 4

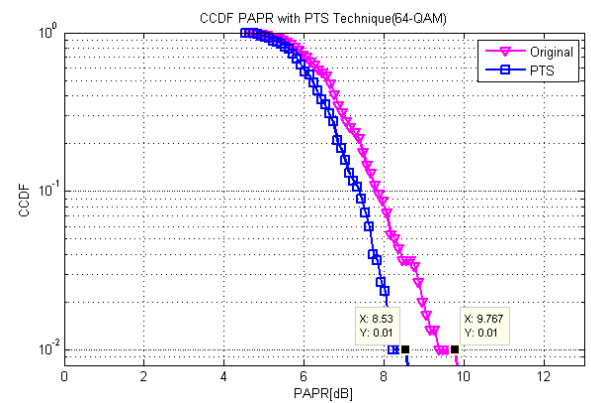

Gambar 6. Grafik CCDF untuk 64-QAM Sub-block 2 


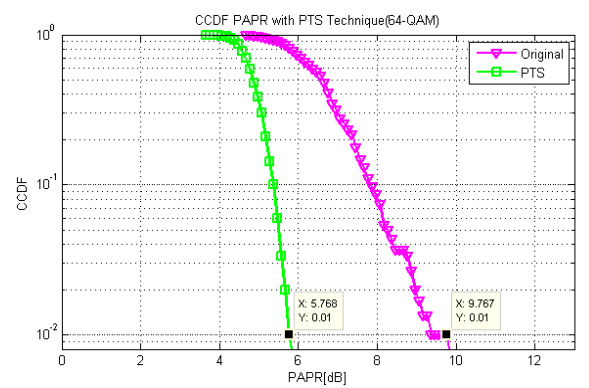

Gambar 7. Grafik CCDF untuk 64-QAM Sub-block 4

\section{B. Analisis Pengaruh BER (Bit Error Ratio)}

Hasil perbandingan kurva BER modulasi M-QAM untuk implementasi WARP diukur pada gain tinggi 50-60 dB. Hal itu dikarenakan pada gain tinggi rentan terkena distorsi nonlinear yang disebabkan oleh komponen power amplifier. Pengukuran dilakukan sebanyak 10 kali untuk setiap gain dan kemudian dihitung rata-ratanya. Dari hasil pengukuran didapatkan nilai BER seperti pada tabel 4. Prosentase penurunan nilai BER terbesar terjadi pada gain 56dB sebesar $95.58 \%$ untuk 16-QAM dan gain 52dB sebesar $82.17 \%$ untuk 64-QAM. Hal itu menunjukkan bahwa sistem OFDM implementasi teknik PTS dapat mereduksi nilai BER lebih baik dibandingkan dengan skema OFDM tanpa teknik reduksi PAPR. Namun kemampuan reduksinya terbatas karena dari hasil pengukuran untuk modulasi 16-QAM nilai BER pada gain 60dB dan untuk modulasi 64-QAM mulai gain 58dB nilai BER yang didapatkan hampir sama untuk kedua skema bisa dilihat pada kurva gambar 8 dan 9. Hal itu dikarenakan pengaruh distorsi nonlinier pada komponen power amplifier di WARP.

Tabel 4.

Perbandingan Kurva BER Modulasi M-QAM

\begin{tabular}{lllll}
\hline \hline Modulasi & $\begin{array}{l}\text { Gain } \\
(\mathrm{dB})\end{array}$ & $\begin{array}{l}\text { Rata-Rata } \\
\text { BER OFDM }\end{array}$ & $\begin{array}{l}\text { Rata-Rata } \\
\text { BER PTS }\end{array}$ & $\begin{array}{l}\text { Prosentase } \\
\text { Penurunan BER (\%) }\end{array}$ \\
\hline 16-QAM & 56 & 0.0002716 & 0.000012 & $95.58 \%$ \\
& 58 & 0.0015157 & 0.000318 & $79.019 \%$ \\
& 60 & 0.0062616 & 0.004641 & $25.88 \%$ \\
$64-$-QAM & 50 & 0.000105 & 0.000023 & $78.095 \%$ \\
& 52 & 0.000573 & 0.000081 & $85.863 \%$ \\
& 54 & 0.00341 & 0.000608 & $82.170 \%$ \\
& 56 & 0.016551 & 0.009081 & $45.133 \%$ \\
& 58 & 0.043217 & 0.036376 & $15.829 \%$ \\
& 60 & 0.0866645 & 0.054138 & $37.517 \%$ \\
\hline \hline
\end{tabular}

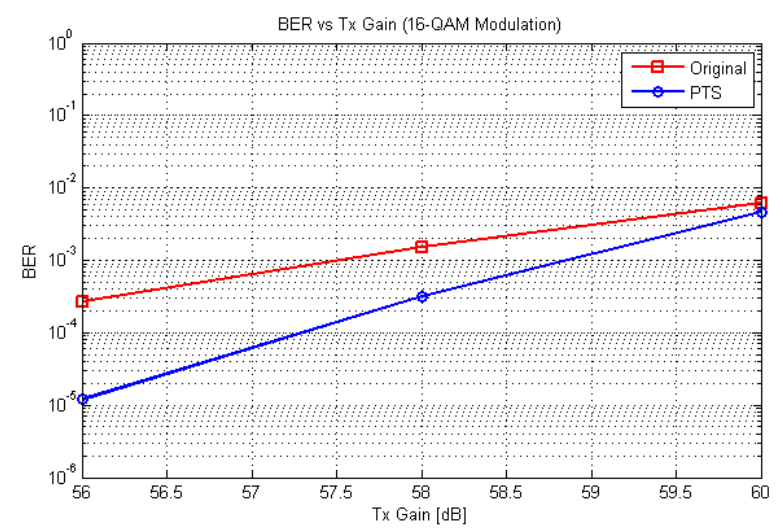

Gambar 8. Perbandingan Kurva BER Modulasi 16-QAM

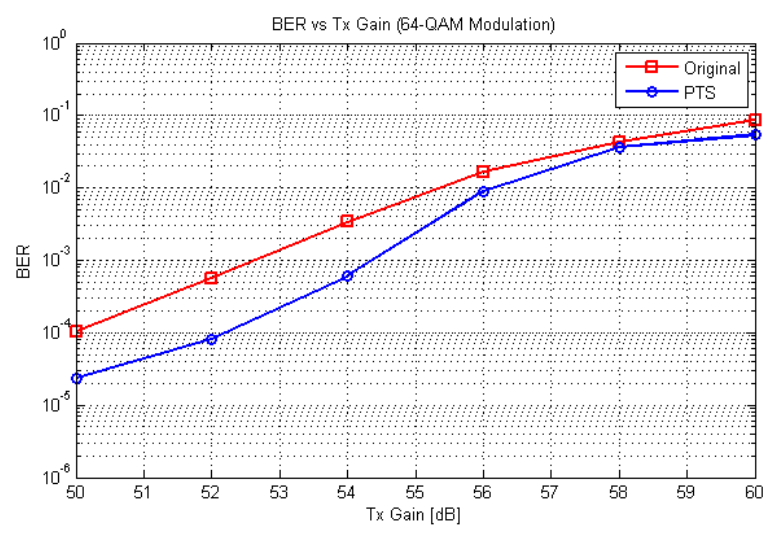

Gambar 9. Perbandingan Kurva BER Modulasi 64-QAM

\section{Analisis Scatter Plot}

Scatter Plot dengan pengaruh distorsi nonlinier yang disebabkan oleh komponen power amplifier pada WARP ditunjukkan pada gambar 10. Hasil scatter plot yang didapat pada saat pengukuran menyebar dan tidak jatuh tepat pada decision area sehingga menimbulkan munculnya kesalahan bit di penerima. Hal itu disebabkan oleh in band distortion sebagai efek dari ketidaklinearan komponen power amplifier pada WARP. Jika dibandingkan pada gambar 11 yaitu scatter plot tanpa distorsi nonlinier menunjukkan hasil scatter plot simbol OFDM di penerima jatuh tepat pada decision area. Sehingga pengaruh in band distortion pada komponen power amplifier dapat menyebabkan titik-titik simbol menyebar yang menyebabkan munculnya nilai BER pada gain tinggi.

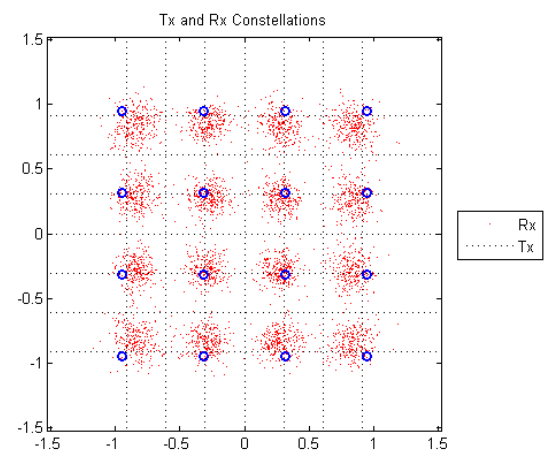

Gambar 10. Konstelasi Dengan Distorsi Nonlinear

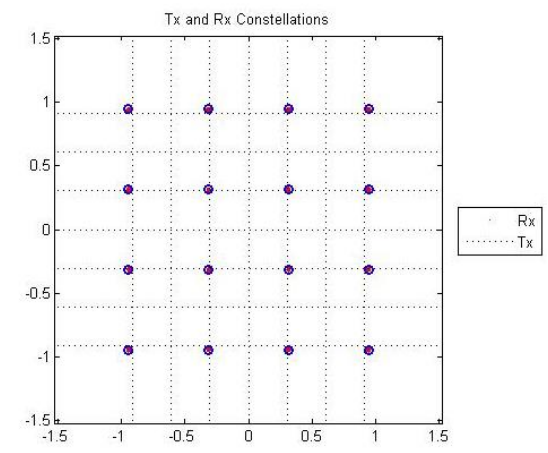

Gambar 11. Konstelasi Tanpa Distorsi Nonlinear 


\section{Analisis Spektrum OFDM}

Hasil spektrum implementasi WARP dapat ditunjukkan pada gambar 12 dan gambar 13. Berdasarkan kedua gambar tersebut, spektrum OFDM pada receiver mengalami kenaikan magnitude side lobe yang disebabkan oleh out of band distortion dari komponen power amplifier. Dengan menggunakan teknik PTS maka kenaikan magnitude side lobe dapat direduksi. Sehingga jarak antar side lobe menjadi lebih besar jika dibandingkan dengan skema OFDM tanpa teknik PTS. Jadi hasil dari spektrum OFDM implementasi teknik PTS untuk kenaikan magnitude side lobe pada receiver menjadi lebih kecil jika dibandingkan dengan skema OFDM tanpa teknik PTS.
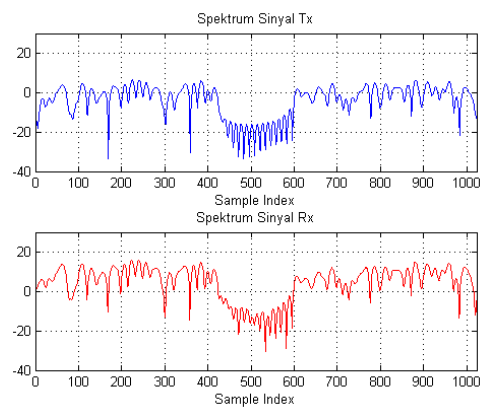

Gambar 12. Hasil Spektrum OFDM
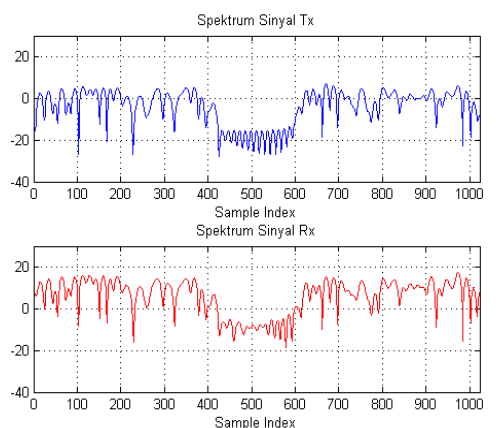

Gambar 13. Hasil Spektrum OFDM-PTS

\section{KESIMPULAN DAN SARAN}

Pada sistem OFDM implementasi teknik PTS modulasi MQAM mampu mereduksi nilai PAPR untuk meningkatkan kinerja OFDM. Semakin besar jumlah sub-block semakin tinggi kemampuan reduksinya. Hal ini dapat dilihat pada hasil pengukuran untuk modulasi 64-QAM dengan sub-block 4 memiliki kemampuan reduksi PAPR sebesar $40.94 \%$. Sedangkan untuk analisa penurunan BER paling tinggi terjadi pada saat gain 56 dengan modulasi 16-QAM yaitu sebesar 95.58\%. Pengaruh distorsi nonlinear pada WARP mampu mempengaruhi konstelasi simbol dan spektrum OFDM. Hal itu dikarenakan adanya in band dan out of band distortion yang disebabkan komponen power amplifier pada WARP.

Dalam penelitian selanjutnya variasi sub-block dan subcarrier bisa diterapkan untuk mengetahui ketahanan kinerja PTS dalam mereduksi efek distorsi nonlinear pada WARP.

\section{UCAPAN TERIMA KASIH}

Penulis Rizkha Ajeng Rochmatika mengucapkan terima kasih kepada Ibu Dr.Ir. Titiek Suryani, M.T. dan Bapak Dr.Ir.
Suwadi, M.T. atas ilmu dan waktunya yang telah diberikan selama bimbingan dalam pengerjaan tugas akhir ini.

\section{DAFTAR PUSTAKA}

[1] Zeyid T. Ibraheem, dkk. Performance Comparison Of Partitioning PTS Based PAPR Reduction Of OFDM Systems Under Different Modulations Techniques. Journal of Theoretical and Applied Information Technology Vol. 66, No. 3, 2014

[2] Sukmawardi Ichsan, Implementasi Dan Analisa Reduksi PAPR Sinyal OFDM Dengan Metode Partial Transmit Sequence (PTS) Pada DSK TMS320C6416T. Teknik Elektro ITS. 2014.

[3] Pooria Varahram., Borhanuddin Mohd Ali., A Low Complexity Partial Transmit Sequence for Average Power Ratio Reduction in OFDM Systems. Radio Engineering Vol. 20, No. 3, 2011

[4] Agrawal Anand., Gill Ashok Kumar., PAPR Reduction of an OFDM Signal using Partial Transmit Sequence (PTS) Technique. International Journal of Mobile Communication \& Networking Vol. 2, No. 1, 2011.

[5] Titiek Suryani., Suwadi., dkk., Implementasi and Performance Evoluation of Orthogonal Frequency Division Multiplexing (OFDM) using WARP, International Seminar on Intellegent Technology and Its Applications, 2015.

[6] Cho, Yong Soo., Jaekwon Kim., Won Young Yang., Chung-Gu Kang, MIMO-OFDM Wireless Communication with MATLAB. John Wiley \& Sons (Asia) Pte Ltd, Singapore, 2010.

[7] Deepika, Rajiv Dahiya, PAPR Reduction in Multi-Carier Transmission Based on Partial Transmit Sequence. International Journal of Engineering Science and Innovative Technology Vol. 3, Issue 4, 2014.

[8] Peter Jantunen, Modelling of Nonlinear Power Amplifier for Wireless Communication. Helsinki University of Technology. 2004.

[9] Tushar Kanti Roy.,Monir Morshed.High Power Amplifier Effect Analysis for OFDM System.International Journal of Science, Engineering and Technology Research Vol. 2, Issue 5, 2013. 